\title{
HUBUNGAN ANTARA PEMBELAJARAN STAD DAN PEMBELAJARAN AUDIO VISUAL DENGAN HASIL BELAJAR PKN DI SMK PGRI PAMIJAHAN BOGOR
}

\author{
Jayadi Syarif ${ }^{1}$, Nurhayati ${ }^{2}$, Kendra Hartaya ${ }^{3}$ \\ Program Studi Teknologi Pendidikan Pascasarjana UIKA Bogor \\ JI. KH. Sholeh Iskandar Km. 2 Kd. Badak, Bogor \\ (jayadisyarief@yahoo.co.id)
}

\begin{abstract}
Abstrak: Penelitian ini adalah untuk mengetahui hubungan antara pembelajaran STAD dan pembelajaran media audio visual dengan hasil belajar PKn di SMK PGRI Pamijahan, baik secara sendiri-sendiri (parsial) maupun besama-sama (simultan). Metode penelitian yang digunakan adalah metode penelitian kuantitatif dengan pendekatan korelasional. Populasi terjangkau penelitian ini berjumlah sebanyak 134 orang siswa. Secara keseluruhan jumlah sampel yang diambil sebanyak 100 orang siswa. Dari hasil analisis data disimpulkan sebagai berikut: (1) pembelajaran STAD berhubungan positif dengan hasil belajar PKn sebesar 0,403. Besarnya kontribusi pembelajaran STAD terhadap hasil belajar PKn sebesar 16,2. (2) respon siswa terhadap pembelajaran media Audio Visual berhubungan positif dengan hasil belajar PKn sebesar 0,239. Besarnya kontribusi pembelajaran media audio visual terhadap hasil belajar PKn sebesar 5,7\%. (3) pembelajaran STAD dan pembelajaran media Audio Visual secara simultan berhubungan positif dengan hasil belajar PKn sebesar 0.461. Besarnya kontribusi kedua variabel secara simultan terhadap hasil belajar PKn sebesar $21,2 \%$.
\end{abstract}

Kata Kunci: Model Pembelajaran STAD, Media Pembelajaran Audio Visual, Hasil Belajar

Abstract : The research was to determine the relationship between STAD and audio-visual media with outcome of civics learning in SMK PGRI Pamijahan. The method used is quantitative research methods with the correlational approach. Affordable population 134 students. Samples taken 100 students. From the analysis of the data summarized as: (1) learning by STAD positively related to outcomes Civics learning by 0.403. The amount of contribution to the STAD of Civics learning is 16.2. (2) students' response to media Audio Visual learning is positively related to outcomes Civics learning by 0.239. The amount of audio-visual media such lessons to learn Civics result of $5.7 \%$. (3) The STAD and Audio Visual media learning simultaneously positively related to learning outcomes for 0461 Civics learning. The contribution of both variables simultaneously to the outcomes civic learning of $21.2 \%$.

Keyword: STAD, Audio Visual Learning, Outcomes Civics Learning

\section{PENDAHULUAN}

\subsection{Latar Belakang}

Model pembelajaran, dipandang memiliki peran strategis dalam upaya mendongkrak keberhasilan proses pembelajaran dikarenakan kondisi kebutuhan siswa, sehingga guru diharapkan mampu menyampaikan materi dengan tepat tanpa mengakibatkan siswa mengalami kebosanan. Dalam proses pembelajaran, khusunya pada mata pelajaran Pendidikan Kewarganegaraan $(\mathrm{PKn})$, tidak semua materi dapat disampaikan dengan model ceramah atau konvensional. salah satunya adalah dengan menggunakan model pembelajaran kooperatif tipe Student Team Achievement Division (STAD.

Selain model pembelajaran, media pembelajaran merupakan komponen yang mempunyai peranan penting dalam proses pembelajaran. Penggunaan media pembelajaran akan membantu efektifitas penyampaian pesan dan materi pelajaran. Media pembelajaran, juga dapat membangkitkan motivasi dan minat siswa 
dalam belajar, serta dapat membantu siswa meningkatkan pemahaman tentang materi yang diajarkan. Penggunaan media interaktif audio visual akan lebih dapat membantu pemahaman siswa untuk memindahkan hal yang abstrak ke konkrit. Terlebih jika menghadirkan benda asli di sekeliling siswa, contoh sederhana pemutaran film yang bercerita tentang gotong royong, kehidupan demokrasi, dan sebagainya, pada materi PKn. Materi-materi tersebut akan lebih mudah dipahami dan dikenang oleh siswa, hal ini tentu sangat berbeda jika hanya diceritakan (verbalisme) saja.

Tujuan penting lain dari pembelajaran kooperatif tipe STAD adalah untuk rnengajarkan kepada siswa keterampilan kerjasama dan kolaborasi. Keterampilan ini amat penting untuk dimiliki di dalam masyarakat di mana banyak kerja orang dewasa sebagian besar dilakukan dalam organisasi yang saling bergantung sama lain dan di mana masyarakat secara budaya semakin beragam. Dalam pembelajaran kooperatif tipe STAD tidak hanya mempelajari materi saja. Namun siswa juga harus mempelajari keterampilan-keterampilan khusus yang disebut keterampilan kooperatif. keterampilan kooperatif ini berfungsi untuk melancarkan hubungan, kerja dan tugas. Peranan hubungan kerja dapat di bangun dengan mengembangkan komunikasi antar anggota kelompok sedangkan peranan tugas dilakukan dengan membagi tugas antar anggota kelompok selama kegiatan.

Walaupun media pembelajaran Audio Visual memiliki kelemahan seperti kesulitan mendapatkan atau memproduksinya, namun media pembelajaran Audio Visual memiliki keunggulan dibandingkan media lainnya dan sesuai untuk digunakan dalam pembelajaran. Keunggulan media pembelajaran Audio Visual adalah dapat menampilkan gambar bergerak yang disertai suara sekaligus. Media pembelajaran Audio Visual dapat menggambarkan suatu obyek yang bergerak bersama-sama dengan suara alamiah atau suara yang sesuai. Dengan menggunakan media pembelajaran Audio Visual maka informasi berupa peristiwa, fakta, konsep dan sebagainya dapat dihadirkan ke dalam ruang kelas.

Keunggulan lain dari penggunaan media pembelajaran Audio Visual adalah dapat merangsang keinginan belajar (stimulate appetite to learn), memotivasi untuk keberhasilan belajar (motivate use of a strategy by showing its success) dan sebagainya.

Dari pendapat ini maka dapat disimpulkan bahwa media pada umumnya dan media pembelajaran Audio Visual khususnya dapat membangkitkan semangat siswa untuk belajar. Dengan adanya semangat tersebut berarti siswa telah termotivasi untuk belajar. Dengan adanya aktivitas belajar maka berkemungkinan besar dapat pula menimbulkan hasil belajar yang tinggi pula.

Pembelajaran yang menyenangkan akan membuat hasil belajar lebih baik dan bermakna. Kerangka berpikir penelitian ini, menunjukkan bahwa pengaruh penggunaan model pembelajaran STAD dan media pembelajaran Audio Visual dalam pembelajaran diduga dapat meningkatkan aktivitas, dan hasil belajar siswa.

\subsection{Rumusan Masalah}

Berdasarkan latar belakang masalah, maka rumusan masalah penelitian adalah:

1. Apakah terdapat hubungan antara pembelajaran STAD dengan hasil belajar PKn di SMK PGRI Pamijahan-Bogor?

2. Apakah terdapat hubungan antara pembelajaran menggunakan media Audio Visual dengan hasil belajar PKn di SMK PGRI Pamijahan-Bogor?

3. Apakah terdapat hubungan antara pembelajaran STAD dan pembelajaran menggunakan media Audio Visual secara bersama-sama dengan hasil belajar PKn di SMK PGRI Pamijahan?

\subsection{Tujuan Penelitian}

Tujuan yang ingin dicapai dari kegiatan penelitian ini untuk mengetahui:

1. Hubungan pembelajaran STAD dengan hasil belajar PKn di SMK PGRI Pamijahan. 
2. Hubungan pembelajaran menggunakan media audio visual dengan hasil belajar PKn di SMK PGRI Pamijahan.

3. Hubungan pembelajaran STAD dan pembelajaran menggunakan media audio visual secara bersama-sama dengan hasil belajar PKn di SMK PGRI Pamijahan.

\section{TINJAUAN TEORI}

\subsection{Kerangka Teoritik}

\subsubsection{Hakikat Hasil Belajar Pendidikan Kewarganegaraan (PKn)}

Hasil belajar merupakan tujuan akhir dilaksanakannya kegiatan pembelajaran di sekolah. Hasil belajar dapat ditingkatkan melalui usaha sadar yang dilakukan secara sistematis mengarah kepada perubahan yang positif yang kemudian disebut dengan proses belajar.

Akhir dari proses belajar adalah perolehan suatu hasil belajar siswa. Hasil belajar siswa di kelas terkumpul dalam himpunan hasil belajar kelas. Semua hasil belajar tersebut merupakan hasil dari suatu interaksi tindak belajar dan tindak mengajar. Dari sisi guru, tindak mengajar diakhiri dengan proses evaluasi hasil belajar, sedangkan dari sisi siswa, hasil belajar merupakan berakhirnya penggal dan puncak proses belajar.

Menurut Sudjana, hasil belajar adalah kemampuan yang dimiliki siswa setelah menerima pengalaman belajar. Selanjutnya Warsito dalam Depdiknas, mengemukakan bahwa hasil dari kegiatan belajar ditandai dengan adanya perubahan perilaku ke arah positif yang relatif permanen pada diri orang yang belajar. Sehubungan dengan pendapat itu, maka Wahidmurni, dkk, menjelaskan bahwa sesorang dapat dikatakan telah berhasil dalam belajar jika ia mampu menunjukkan adanya perubahan dalam dirinya. Perubahan-perubahan tersebut diantaranya dari segi kemampuan berpikirnya, keterampilannya, atau sikapnya terhadap suatu objek.
Jika dikaji lebih mendalam, maka hasil belajar dapat tertuang dalam taksonomi Bloom, yakni dikelompokkan dalam tiga ranah (domain) yaitu domain kognitif atau kemampuan berpikir, domain afektif atau sikap, dan domain psikomotor atau keterampilan.

Mata Pelajaran Pendidikan Kewarganegaraan merupakan mata pelajaran yang memfokuskan pada pembentukan warganegara, untuk memahami dan mampu melaksanakan hak-hak dan kewajibannya menjadi warganegara Indonesia yang cerdas, terampil, dan berkarakter yang diamanatkan oleh Pancasila dan UUD 1945.

Hasil belajar PKn adalah perubahan perilaku secara positif serta kemampuan yang dimiliki siswa, yaitu kemampuan siswa dalam menguasai materi PKn berdasarkan hasil dari pengalaman atau pelajaran setelah mengikuti pembelajaran secara periodik dalam kelas dari suatu interaksi tindak proses pembelajaran berupa hasil belajar intelektual, strategi kognitif, sikap dan nilai, inovasi verbal, serta hasil belajar motorik. Perubahan tersebut dapat diartikan terjadinya peningkatan dan pengembangan yang lebih baik dibandingkan dengan sebelumnya.

\subsubsection{Hakikat Model Pembelajaran Kooperatif Tipe STAD \\ Model pembelajaran merupakan cara atau teknik penyajian materi ajar yang digunakan oleh guru dalam proses pembelajaran, agar tercapai tujuan pembelajaran.}

Model pembelajaran STAD merupakan salah satu bentuk pembelajaran kooperatif yang mendorong siswa saling membantu, memotivasi, serta menguasai ketrampilan yang diberikan oleh guruPembelajaran kooperatif tipe STAD merupakan strategi belajar dengan sejumlah siswa sebagai anggota kelompok kecil yang tingkat kemampuannya berbeda. Dalam menyelesaikan tugas kelompoknya, setiap siswa anggota kelompok harus saling bekerja sama dan saling membantu untuk memahami materi pelajaran. 


\subsubsection{Hakikat Media Pembelajaran Audio Visual \\ Media pembelajaran merupakan} wahana atau jembatan untuk mencapai tujuan pembelajaran. Penggunaan media pembelajaran dapat memberi arti pada pengakuan terhadap hakikat individu sebagai makhluk yang memiliki kekhususan sendiri, berbeda dalam menghadapi problem, baik dalam tingkat kecepatan maupun dalam tingkat ketelitiannya. Seseorang akan lebih mudah mempelajari sesuatu melalui pendengaran daripada penglihatannya atau sebaliknya.

Secara umum, semua mata pelajaran akan lebih efektif jika diajarkan dengan media yang sesuai. Oleh karena itu, guru harus mengetahui terlebih dahulu materi dan tujuan pembelajaran. Audio-visual merupakan salah satu media untuk membuat pembelajaran lebih dinamis dan menyenangkan. Media Pembelajaran diartikan sebagai segala sesuatu yang dapat digunakan untuk menyalurkan pesan (massage), merangsang pikiran, perasaan, perhatian dan kemauan siswa sehingga dapat mendorong proses belajar. Media pembelajaran Audio Visual dapat diartikan sebagai alat yang dapat membantu proses pembelajaran dan berfungsi untuk memperjelas makna pesan belajar yang disampaikan, dengan menggunakan lebih dari satu media yang dapat langsung didengar dan dipandang dengan sistem yang mendukung penggunaan teks interaktif, dan audio, gambar diam, video dan grafik, sehingga dengan menggunakan media tersebut proses pembelajaran dapat mencapai tujuan dengan lebih baik dan sempurna.

\subsection{Kerangka Berfikir}

\subsubsection{Hubungan Model Pembelajaran STAD dengan Hasil Belajar PKn}

Inti dari model pembelajaran STAD adalah guru menyampaikan materi, kemudian siswa bergabung dalam kelompoknya yang terdiri atas empat atau lima orang untuk menyelesaikan soal-soal yang diberikan oleh guru. Oleh karena penggunaan model pembelajaran STAD bisa menstimulus siswa untuk berani aktif berbicara dalam kegiatan pembelajaran., maka otomatis pikiran siswa hanya terfokus pada pembelajaran. Diharapkan melalui pembelajaran kooperatif dengan tipe STAD dapat meningkatkan hasil dan aktivitas belajar PKn siswa.

Model pembelajaran tipe STAD diharapkan akan meningkatkan semangat kebersamaan dan saling membantu dalam menguasai materi. Sehingga siswa dapat meningkatkan pemahaman yang optimal terhadap mata pelajaran sehingga hasil pembelajaran sesuai dengan yang diharapkan melalui peningkatan aktivitas belajar PKn.

\subsubsection{Hubungan Media Pembelajaran Audio Visual dengan Hasil Belajar PKn}

Dengan adanya media sebagai alat perantara misalnya visual yaitu berupa gambar, model, obyek dan bentuk visual lainnya, menjadikan hasil belajar peserta didik itu meningkat. Peserta didik akan lebih tertarik lagi jika digunakan alat audio visual yang akan memperjelas materi yang diterangkan oleh pendidik karena dalam pengajaran dengan menggunakan audio visual akan memperoleh melalui pengalaman konkret, tidak hanya melalui kata-kata belaka.

Peralatan audio visual tidak harus digolongkan sebagai pengalaman belajar yang diperoleh dari penginderaan pandang dan dengar, tetapi alat yang dapat memberikan dan memperkaya pengalaman yang berbeda pada siswa. Dengan menggunakan media Audio Visual akhirnya diharapkan dapat mempertinggi mutu hasil belajar yang dicapai oleh peserta didik.

\subsubsection{Hubungan Model Pembelajaran STAD dan Media Audio Visual dengan Hasil Belajar PKn \\ Model pembelajaran kooperatif tipe} STAD merupakan suatu model pengajaran dimana siswa belajar dalam kelompok kelompok kecil yang memiliki tingkat kemampuan berbeda. Dalam menyelesaikan tugas kelompok, setiap anggota saling kerjasama dan membantu untuk memahami suatu bahan pembelajaran.

Model Pembelajaran kooperatif tipe STAD sangat berbeda dengan model pengajaran langsung. $\mathrm{Di}$ samping model 
pembelajaran kooperatif dikembangkan untuk mencapai hasil belajar akademik, model pembelajaran kooperatif juga efektif untuk rnengembangkan keterampilan sosial siswa. Beberapa ahli berpendapat bahwa model ini unggul dalarn membantu siswa memahami konsep konsep yang sulit. Para pengembang model ini telah menunjukkan bahwa model struktur penghargaan kooperatif telah dapat meningkatkan penilaian siswa pada belajar akademik, dan perubahan norma yang berhubungan dengan hasil belajar.

Dalam banyak kasus, norma budaya anak muda sebenarnya tidak menyukai siswa siswa yang ingin menonjol secara akademis. Robert Slavin dan pakar lain telah berusaha untuk mengubah norma ini rnelalui penggunaan pembelajaran kooperatif. Di samping mengubah norma yang berhubungan dengan hasil belajar, pembelajaran kooperatif dapat memberikan keuntungan baik pada siswa kelompok bawah maupun kelompok atas kerja bersama menyelesaikan tugas tugas akademik, siswa kelompok atas akan menjadi tutor bagi siswa kelompok bawah, jadi memperoleh bantuan khusus dari teman sebaya, yang memiliki orientasi dan bahasa yang sama, sehingga dapat meningkatkan motivasi belajar.

Penggunaan model cooperative learning metode Student Teams Achievement Divisions (STAD) berpengaruh positif terhadap aktivitas siswa. Siswa merasa tertantang atau termotivasi untuk menguasai dan mendalami materi pembelajaran. Siswa dengan motivasi belajar yang tinggi dapat lebih meningkatkan hasil belajarnya ke level yang lebih baik lagi. Demikian juga siswa yang memiliki motivasi belajar rendah akan termotivasi untuk menguasai dan membuat hasil belajarnya membaik dari sebelumnya.

Media pada umumnya dan media pembelajaran Audio Visual khususnya dapat membangkitkan semangat siswa untuk belajar. Dengan adanya semangat tersebut berarti siswa telah termotivasi untuk belajar. Dengan adanya aktivitas belajar maka berkemungkinan besar dapat pula menimbulkan hasil belajar yang tinggi pula.

\subsection{Hipotesis Penelitian}

Hipotesis dalam penelitian ini adalah :

Ho : Tidak terdapat hubungan yang signifikan antara pembelajaran STAD dengan hasil belajar PKn siswa SMK PGRI Pamijahan

$\mathrm{Ha}$ : Terdapat hubungan yang signifikan antara pembelajaran STAD dengan hasil belajar PKn siswa SMK PGRI Pamijahan

Ho : Tidak terdapat hubungan yang signifikan antara pembelajaran menggunakan media audio visual dengan hasil belajar PKn siswa SMK PGRI Pamijahan

$\mathrm{Ha}$ : Terdapat hubungan yang signifikan antara pembelajarana menggunaan media audio visual dengan hasil belajar PKn siswa SMK PGRI Pamijahan

Ho : Tidak terdapat hubungan yang signifikan antara pembelajaran STAD dan pmbelajaran menggunakan media audio visual dengan hasil belajar PKn siswa SMK PGRI Pamijahan

$\mathrm{Ha}$ : Terdapat hubungan yang signifikan antara pembelajaran STAD dan pembelajaran menggunakan media audio visual dengan hasil belajar PKn siswa SMK PGRI Pamijahan

\section{METODOLOGI PENELITIAN}

\subsection{Waktu dan Tempat Penelitian}

Penelitian ini dilakukan di SMK PGRI

Pamijahan Kecamatan Pamijahan Kabupaten Bogor. Waktu penelitian dimulai dari bulan Nopember 2013 s/d Januari 2014.

\subsection{Metode Penelitian}

Metode penelitian yang digunakan dalam penelitian adalah metode survey dengan pendekatan korelasional. Kontelasi masalah penelitian dapat dilihat pada gambar 1. 


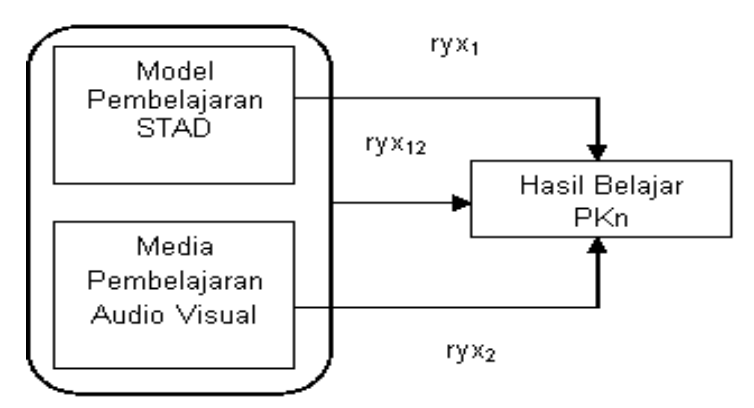

Gambar 1 Konstelasi Masalah Penelitian

\subsection{Populasi dan Sampling}

Populasi penelitian ini adalah siswa SMK yang berada di kecamatan Pamijahan Kabupaten Bogor, terdiri dari 7 Sekolah Menengah Kejuruan (SMK) dengan jumlah siswa sebanyak 1320 orang. Secara keseluruhan jumlah sampel yang diambil sebanyak 100 orang siswa.

\subsection{Instrumen Penelitian}

Instrumen penelitian dalam bentuk kuesioner terdiri dari: 1) kuesioner model pembelajaran, 2) kuesioner media audio visual, 3) Nilai Test.

\subsection{Teknik Analisis Data Uji Korelasi Sederhana}

Teknik korelasi sederhana yang digunakan dalam peneitian ini adalah Product Moment. Hal ini dimaksudkan untuk melihat hubungan antara variabel dalam penelitian. Korelasi sederhana ini untuk menguji hipotesis pertama dan hipotesis kedua.

\section{Uji Korelasi Ganda}

Uji ini dimaksudkan untuk menguji hipotesis ketiga, yang bertujuan untuk melihat apakah terdapat korelasi yang berarti apabila kedua variabel bebas secara bersama-sama dikorelasikan dengan variabel terikat.

\section{Uji Korelasi Parsial}

Uji Korelasi Parsial digunakan untuk mengetahui hubungan antara satu variabel bebas dengan variabel terikat dan sebaliknya, jika variabel bebas lainnya dikendalikan atau dijaga tetap (tidak berubah).

\section{HASIL DAN PEMBAHASAN}

\subsection{Hubungan Pembelajaran STAD $\left(X_{1}\right)$ dengan Hasil Belajar PKn (Y)}

Tabel 1 Model Summary

\begin{tabular}{lr}
\hline & Model 1 \\
\hline $\mathrm{R}$ & $.403^{\mathrm{a}}$ \\
$\mathrm{R}$ Square & .162 \\
Adjusted R Square & .154 \\
Std. Error of the & 2.90688 \\
Estimate & \\
a. Predictors: (Constant), & \\
Model_STAD & \\
\hline
\end{tabular}

Tabel 2 Coefficients $^{a}$

\begin{tabular}{rr}
\hline \multicolumn{2}{c}{ Model 1 } \\
\hline (Constant) & Model_STAD \\
11.232 & .117 \\
2.111 & .027 \\
5.320 & 4.360 \\
.000 & .000 \\
\hline
\end{tabular}

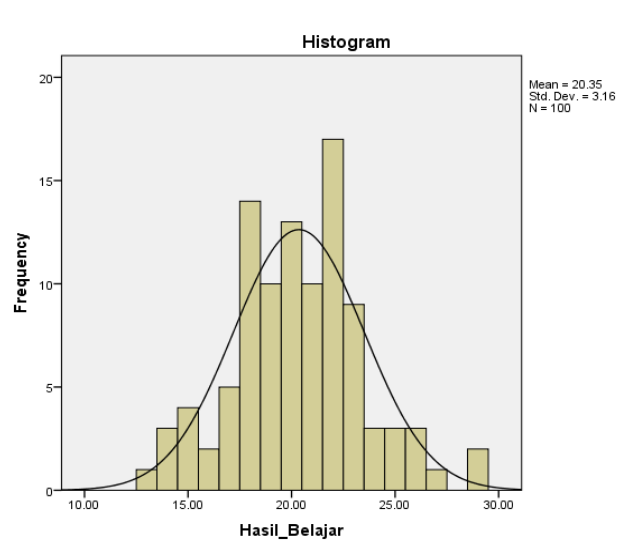

Gambar 2 Grafik Data Hasil Belajar

Terdapat hubungan positif dan signifikan antara pembelajaran STAD $\left(X_{1}\right)$ dengan hasil belajar PKn (Y). Kekuatan hubungan antara pembelajaran STAD $\left(X_{1}\right)$ dengan hasil belajar PKn (Y) ditunjukkan dengan koefisien korelasi $r_{y 1}=0,403$ (lihat tabel 1) dan koefisien determinasi $r^{2}{ }_{y 1}=0,162$ artinya bahwa pembelajaran STAD $\left(X_{1}\right)$ memberikan kontribusi sebesar 16,2\% terhadap hasil belajar PKn (Y). Hubungan fungsional antara pembelajaran STAD $\left(\mathrm{X}_{1}\right)$ dengan hasil belajar PKn $(Y)$ ditunjukkan oleh persamaan regresi $\hat{Y}=11,232+0,117 \mathrm{X}_{1}$ (lihat tabel 2) yang berarti setiap kenaikan satu satuan pembelajaran STAD $\left(X_{1}\right)$ diprediksi dapat meningkatkan hasil belajar PKn (Y) 
sebesar 0,117 satuan dengan konstanta 11,232 .

\subsection{Hubungan Pembelajaran Media Audio Visual $\left(\mathbf{X}_{2}\right)$ dengan Hasil Belajar PKn}

Tabel 3 Model Summary

\begin{tabular}{lr}
\hline & Model 1 \\
\hline $\mathrm{R}$ & $.239^{\mathrm{a}}$ \\
$\mathrm{R}$ Square & .057 \\
Adjusted R Square & .048 \\
Std. Error of the & 3.08425 \\
Estimate & \\
a. Predictors: Predictors: (Constant), \\
Media_AV
\end{tabular}

Tabel 4 Coefficients ${ }^{a}$

\begin{tabular}{rr}
\hline \multicolumn{2}{c}{ Model 1 } \\
\hline (Constant) & Media_AV \\
15.409 & .063 \\
2.051 & .026 \\
& .239 \\
7.514 & 2.437 \\
\hline
\end{tabular}

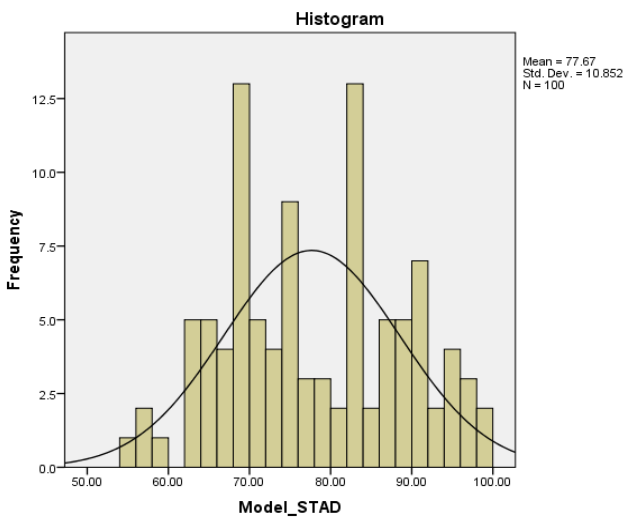

Gambar 3 Grafik Data Media Audio Visual

Terdapat hubungan positif dan signifikan antara pembelajaran media audio visual $\left(\mathrm{X}_{2}\right)$ dengan hasil belajar $\mathrm{PKn}(\mathrm{Y})$. Kekuatan hubungan antara pembelajaran media audio visual $\left(X_{2}\right)$ dengan hasil belajar PKn ( $Y$ ) ditunjukkan dengan koefisien korelasi $r_{y 1}=0,239$ dan koefisien determinasi $r_{y 1}^{2}=$ 0,057 (lihat tabel 3) artinya bahwa pembelajaran media audio visual $\left(\mathrm{X}_{2}\right)$ memberikan kontribusi sebesar $5,7 \%$ terhadap hasil belajar PKn $(Y)$. Hubungan fungsional antara pembelajaran media audio visual $\left(\mathrm{X}_{2}\right)$ dengan hasil belajar PKn (Y)ditunjukkan oleh persamaan regresi $\hat{Y}=2,051+0,026 X_{2}$ (lihat tabel 4) yang berarti setiap kenaikan satu satuan pembelajaran media audio viasual $\left(X_{2}\right)$ diprediksi dapat meningkatkan hasil belajar PKn (Y) sebesar 0,026 satuan dengan konstanta 2,051.

\subsection{Hubungan Antara Pembelajaran STAD dan Pembelajaran Pembelajaran Media Audio Visual Secara Bersama-sama dengan Hasil Belajar PKn}

Tabel 5 Model Summary

\begin{tabular}{lrr}
\hline $\mathrm{R}$ & \\
$\mathrm{R}$ Square & & Model 1 \\
Adjusted R Square & $.461^{\mathrm{a}}$ \\
.212 \\
Std. Error of the Estimate & .196 \\
Change Statistics & R Square & 2.83350 \\
& Change & .212 \\
& F Change & 13.076 \\
& df1 & 2 \\
& df2 & 97 \\
& Sig. F Change & .000 \\
\hline
\end{tabular}

\begin{tabular}{rrr}
\multicolumn{3}{c}{ Tabel 6 Coefficients $^{\mathrm{a}}$} \\
\hline \multicolumn{3}{c}{ Model 1 } \\
\hline (Constant) & Media_AV & Model_STAD \\
& .450 & .794 \\
5.660 & 2.478 & 4.372 \\
.000 & .015 & .000 \\
\hline
\end{tabular}

Tabel 7 ANOVA $^{a}$

\begin{tabular}{lrrr} 
& \multicolumn{3}{c}{ Model 1 } \\
\cline { 2 - 4 } & \multicolumn{1}{c}{ Regression } & \multicolumn{1}{c}{ Residual } & \multicolumn{1}{c}{ Total } \\
\hline Sum of & 209.964 & 778.786 & 988.750 \\
Squares & & & 99 \\
df & 2 & 97 & 99 \\
Mean & 104.982 & 8.029 & \\
Square & & & \\
F & 13.076 & & \\
Sig. & $.000^{\mathrm{D}}$ & &
\end{tabular}

a. Dependent Variable: Hasil_Belajar

b. Predictors: (Constant), Modèl_STAD, Media_AV

Terdapat hubungan positif dan signifikan antara pembelajaran $\operatorname{STAD}\left(\mathrm{X}_{1}\right)$ dan pembelajaran media Audio Visual $\left(X_{2}\right)$ secara bersama-sama dengan hasil belajar PKn $(\mathrm{Y})$. Keduanya berjalan seiring yang artinya makin tinggi pembelajaran STAD $\left(X_{1}\right)$ dan pembelajaran media Audio Visual $\left(X_{2}\right)$ secara bersama-sama maka makin tinggi pula hasil belajar PKn (Y). Kadar hubungan keduanya ditunjukkan dengan koefisien korelasi $r_{\mathrm{y} .12}=$ 0,461 dan koefisien determinasi $r_{y .12}^{2}=0,212$ 
(lihat tabel 5) yang berarti bahwa pembelajaran STAD $\left(X_{1}\right)$ dan pembelajaran media Audio Visual $\left(X_{2}\right)$ secara bersama-sama mempunyai kontribusi sebesar 21,2\% terhadap hasil belajar PKn (Y). Persamaan regresi $\hat{Y}=11,696+0,118 X_{1}+0,231 X_{2}$ (lihat tabel 6) hal ini berarti setiap kenaikan satu satuan pembelajaran STAD $\left(X_{1}\right)$ dan pembelajaran media Audio Visual $\left(X_{2}\right)$ secara bersama-sama dapat meningkatkan hasil belajar PKn (Y) sebesar 0,349 satuan $(0,1118$ $+0,231$ ) dengan konstanta 11,696.

\subsection{Uji Korelasi Parsial}

Hasil perhitungan korelasi antara $X_{1}$ dengan $Y$ diperoleh koefisien korelasi sebesar $\mathrm{ry}_{{ }_{1} 1}=0,403$ sedangkan hasil perhitungan uji korelasi parsial dengan pengendali $\mathrm{X}_{2}$ diperoleh ry $_{\cdot 1}=0,239$ dengan nilai uji signifikansi thitung > ttabel $(2,433>1,984)$ pada $\alpha=0,05$. Hal ini berarti bahwa hubungan antara pembelajaran STAD $\left(\mathrm{X}_{1}\right)$ dan hasil belajar PKn (Y) tetap signifikan apabila dikontrol oleh variabel pembelajaran media Auido Visual $\left(X_{2}\right)$, dengan kata lain hubungan antara pembelajaran STAD $\left(\mathrm{X}_{1}\right)$ dan hasil belajar IPA $(Y)$ tidak dipengaruhi secara signifikan oleh pembelajaran media audio visual $\left(\mathrm{X}_{2}\right)$

Berdasarkan hasil perhitungan korelasi antara $\mathrm{X}_{2}$ dengan $\mathrm{Y}$ diperoleh koefisien korelasi sebesar $r_{\cdot 2}=0,239$ sedangkan perhitungan uji korelasi parsial dengan pengendali $X_{1}$ diperoleh ry.2 $=0,403$ dengan nilai uji signifikansi thitung > ttabel $(4,355>$ 1,984) pada $\alpha=0,05$. Hal ini berarti bahwa hubungan antara pembelajaran media Audio Visual $\left(\mathrm{X}_{2}\right)$ dan hasil belajar PKn (Y) tetap signifikan apabila dikontrol oleh variabel pembelajaran $\operatorname{STAD}\left(\mathrm{X}_{1}\right)$, dengan kata lain hubungan antara pembelajaran media Audio Visual $\left(\mathrm{X}_{2}\right)$ dengan hasil belajar PKn $(\mathrm{Y})$ tidak dipengaruhi secara signifikan oleh variabel pembelajaran STAD $\left(\mathrm{X}_{1}\right)$.

\section{KESIMPULAN DAN SARAN}

\subsection{Kesimpulan}

1. Terdapat hubungan positif dan sangat signifikan antara pembelajaran STAD $\left(\mathrm{X}_{1}\right)$ dengan hasil belajar PKn (Y).
2. Terdapat hubungan positif dan sangat signifikan antara pembelajaran media audio visual $\left(\mathrm{X}_{2}\right)$ dengan hasil belajar $\mathrm{PKn}$ (Y).

3. Terdapat hubungan positif dan sangat signifikan antara pembelajaran STAD $\left(\mathrm{X}_{1}\right)$ dan pembelajaran media Audio Visual $\left(X_{2}\right)$ secara bersama-sama dengan hasil belajar PKn $(Y)$.

\subsection{Saran}

1. Mempertimbangkan pembelajaran PKn dengan menggunakan model Students Teams Achievement Divisions (STAD) sebagai salah satu alternatif model mengajar yang menarik merupakan sebuah pertimbangan, karena model peembelajaran STAD tidak hanya dapat meningkatkan kualitas afektif siswa tetapi juga prestasi belajar kognitif siswa. Selin itu penerapan metode Students Teams Achievement Divisions (STAD) tidak hanya dapat digunakan pada mata pelajaran PKn, tetapi juga dapat diterapkan pada pelajaran lain.

2. Penggunaan media audio visual lebih diberdayakan karena dengan media tersebut mampu meningkatkan hasil belajar siswa terhadap materi yang disampaikan, dan yang lebih penting tujuan pembelajaran yang telah ditetapkan bisa tercapai. Dengan menggunakan media pembelajaran audio visual terutama yang berhubungan dengan pemanfaatan teknologi, secara langsung bisa meningkatkan kualitas/kompetensi yang dimiliki oleh siswa

3. Peningkatan kemampuan guru dalam menggunakan media Audio Visual sebagai salah satu alternatif cara untuk meningkatkan hasil belajar siswa. Wajib dilakukan untuk meningkatkan kompetensinya, terutama dalam penguasaan model-model pembelajaran agar kemampuan mengajar dapat mengikuti kemajuan dan perkembangan pendidikan. Selain itu menciptakan situasi pembelajaran yang kondusif juga tidak kalah pentingnya, sehingga suasana belajar akan lebih nyaman, dengan menggunakan media pembelajaran dan model pembelajaran yang sesuai dengan 
materi yang sedang dibahas. Dengan demikian siswa akan lebih memahami tentang materi yang sedang dipelajari yang pada akhirnya tujuan pembelajaran akan tercapai sehingga hasil belajar lebih maksimal.

4. Adanya penelitian lanjutan mengenai variabel pembelajaran dengan menggunakan media audio visual dan model pembelajaran STAD, sehingga dapat ditemukan hal-hal yang lebih terperinci dan solusi yang lebih tepat bagaimana kedua variabel tersebut berpengaruh terhadap hasil belajar siswa.

\section{DAFTAR PUSTAKA}

Ahmadi. (2010). Strategi Pembelajaran Sekolah Berstandar Internasional dan Nasional. Jakarta: PT Pustaka Raya.

Ali, Muhammad. (2002). Guru dalam Proses Belajar mengajar. Bandung: Sinar Baru.

Arikunto, Suharsimi. (2007). Prosedur Penelitian Suatu Pendekatan Praktik. Jakarta: Rineka Cipta.

Arsyad, Azhar. (2011). Media Pembelajaran. Jakarta: Rajawali Press.

Asri, Budiningsih. (2009). Belajar dan pembelajaran. Yogyakarta: FIP UNY.

Badudu, J. S. dan Sutan Mohammad Zain. (2004). Kamus Umum Bahasa Indonesia Cet 1. Jakarta: Pustaka Sinar Harapan

Chasmin, Poetra. Zarkasyi. (2009). Mendidik Anak Dalam Keluarga, Majalah Nasehat Perkawinan. Edisi XV. Nomor 188

Daryanto. (2011). Media Pembelajaran. Bandung: Satu Nusa.

Depdiknas, (2010). Bunga Rampai Keberhasilan Guru dalam Pembelajaran (SMA, SMK, dan SLB). Jakarta: Depdiknas.

Dimyati dan Mudjiono. (2009). Belajar dan Pembelajaran. Jakarta: PT Rineka Cipta.

Djamarah, Saiful Bahri (2002). Psikologi belajar. Jakarta: PT Rineka Cipta.
(2006). Strategi

Belajar Mengajar. Jakarta: Rineka Cipta.

Fauzi, Ahmad. (2004). Psikologi Umum Cet. $K e-2$. Bandung: CV Pustaka Setia.

Gunarsa, Singgih D. (1976). Psikologi untuk Keluarga. Jakarta: Gunung Mulia.

Hamalik, Oemar. (2006). Proses Belajar Mengajar. Jakarta: PT Bumi Aksara.

Ibrahim, Hasan. (2008). Pengembangan Media Pembelajaran. Jakarta: Rineka Cipta.

Ikhsan, Amirudin, RA. Mohadjir. (1992). Pendidikan di Lingkungan Keluarga. Jakarta: Harian Tertib.

Kurniawan, Yedi. (1992). Pendidikan Anak Sejak Dini Hingga Masa Depan. Jakarta: CV Shahih Bukhori, Darun Wamunthahabi Al-Sabith, tth Zuz II.Firdaus

Mustofa, Arif. (2011). Belajar dan Pembelajaran. Yogyakarta: Aruzz Media.

Nugraha, Purbasantika. (2009). Motivasi,Dasar Dan Arah Prilaku Artikel Majalah Perkawinan Dan Keluarga

Purwanto, MP. M. Ngalim. (2009). Psikologi Pendidikan. Bandung: PT. Remaja Rosadi Karya.

Purwanto, Sardiman. A. M. Interaksi dan Motivasi Belajar Mengajar. (2006). Jakarta: PT. Raja Grafika Persada.

Puspasari, Irawan. Prasetyo, Suciati dan IGK Wardani. (2006). Teori Belajar, Motivasi dan Keterampilan Mengajar. Jakarta: Universitas Terbuka.

Riyana, Ilyasih. (2008). Pemanfaatan OHP dan Presentasi dalam Pembelajaran. Jakarta: Cipta gung.

Riyana, Ilyasih. (2008). Pemanfaatan OHP dan Presentasi dalam Pembelajaran. Jakarta: Cipta Agung.

Sabri, H.M Alisuf. (2006). Psikologi Pendidikan. Jakarta: Pedoman Imu Jaya. 
Sadiman. (2007). Media Pendidikan. Jakarta:Raja Grafindo Persada.

Sanjaya, Wina. (2010). Perencanaan dan Desain Sistem Pembelajaran. Jakarta: Kencana.

Sardiman, A.M. (2003). Interaksi Dan Minati Belajar Dan Mengajar. Jakarta: Raja Grafindo Persada.

Sudjana. (2006). Metode Statistika. Bandung: Tarsito.

Sudjana, Nana. (2005). Penilaian Hasil Proses Belajar Mengajar. Bandung: PT. Remaja Rosdikarya.

(2006). Teori Belajar dan Pembelajaran. Jakarta: Rineka Cipta.

Sumiati dan Azra. (2010). Metode Pembelajaran. Bandung: CV Wacana Prima.

Thabroni, Muhammad dan Mustofa, Arif. (2011). Belajar dan Pembelajaran: Pengembangan Wacana dan Praktik Pembelajaran dalam Pembangunan Nasional. Yogyakarta: Ar-Ruz Media.

Wahidmurni, Alifin Mustikawan, dan Ali Ridho. (2010). Evaluasi Pembelajaran: Kompetensi dan raktik. Yogyakarta: Nuha Letera.

Wasty, Soemanto. (2000). Psikologi Pendidikan. Jakarta: PT. Rineka Cipta.

Widi, Asih Harini. (2011). Efective \& Powerful Presentation with Power Point 2010. Yogyakarta: ANDI.

Wijaya, Renaldi. (2008). Mendidik Dengan Keteladanan. Majalah Perkawinan dan Keluarga 